\title{
PENGARUH PENDEKATAN PEMBELAJARAN VISUAL THINKING DALAM MENINGKATKAN KEMAMPUAN KONEKSI MATEMATIKA SISWA SD
}

\author{
Muhammad Fendrik, Roby Maiva Putra \\ Pendidikan Guru Sekolah Dasar FKIP Universitas Riau, \\ Bimbingan Konseling FKIP Universitas Riau \\ muhammad.fendrik@lecturer.unri.ac.id,robymaivaputra@lecturer.unri.ac.id
}

\begin{abstract}
ABSTRAK
Tujuan penelitian ini adalah untuk menelaah pengaruh pendekatan pembelajaran visual thinking terhadap kemampuan koneksi matematis. Kuasi eksperimen dengan desain kelompok kontrol non-ekuivalen ini melibatkan 66 siswa kelas $\mathrm{V}$ di salah satu Sekolah Dasar di Kota Pekanbaru. Instrumen yang digunakan berupa soal pretes dan postes. Analisis statitistik yang dilakukan adalah uji ANOVA dua jalur dan uji non-parametrik Kruskal-Wallis. Hasil penelitian yang diperoleh adalah: 1) peningkatan kemampuan koneksi matematis siswa yang memperoleh pembelajaran dengan pendekatan visual thinking tidak berbeda secara signifikan dibanding siswa yang memperoleh pembelajaran konvensional; 2) tidak terdapat interaksi antara pembelajaran (visual thinking dan konvensional) dengan kemampuan matematis siswa (atas, tengah dan bawah) terhadap peningkatan kemampuan koneksi matematis; dan 3) terdapat perbedaan kemampuan koneksi matematis siswa yang memperoleh pembelajaran dengan pendekatan visual thinking ditinjau dari kemampuan matematis siswa (atas, tengah dan bawah).
\end{abstract}

Kata Kunci : visual thinking, koneksi matematis, sekolah dasar

\section{ABSTRACT}

The purpose of this study is to examine the influence of visual thinking approach to the mathematical connections ability. The method is quasi experiments with the design of this non-equivalent control group involved 66 students of fifth grade in one of the Elementary Schools in Pekanbaru. The instrument used is a matter of pretest and post test. The statistical analysis was a two-track ANOVA test and non-parametric Kruskal-Wallis test. The result of the research are: 1) improving students' mathematical connection ability who get learning with visual thinking approach was not significantly different than students who get conventional learning; 2) there is no interaction between learning (visual thinking and conventional) with students' mathematical abilities (upper, middle and lower) on the improving students' mathematical connection ability; and 3) there are differences in students' mathematical connection ability who gain learning with visual thinking approach in terms of mathematical ability of students (top, middle and bottom).

Keywords: visual thinking, mathematical connection ability, elementary school 


\section{PENDAHULUAN}

Kemampuan koneksi matematis sangat diperlukan oleh siswa Sekolah Dasar (SD) sejak dini karena melalui koneksi matematis maka pandangan dan pengetahuan siswa akan semakin luas terhadap matematika sebab semua yang terjadi dikehidupan sehari-hari maupun materi yang dipelajarinya saling berhubungan, konsep pemikiran dan wawasan siswa akan semakin terbuka dan luas terhadap matematika karena siswa akan memandang matematika sebagai suatu bagian yang terintegrasi bukan sebagai sekumpulan topik yang terpisahpisah, serta mengakui adanya keterkaitan atau hubungan dan aplikasi di dalamkehidupan atau lingkungan sekitar siswa. Karena topik-topik dalam matematika banyak memiliki relevansi dengan disiplin ilmu lain, baik di sekolah maupun di luar sekolah maka diperlukan adanya peningkatan kemampuan koneksi matematis dalam pembelajaran matematika.

Kemampuan koneksi matematis merupakan salah satu kemampuan yang perlu dimiliki siswa melalui pembelajaran matematika yang ditetapkan oleh National Council of Teachers of Mathematics (NCTM). Adapun keterampilanketerampilan yang perlu dimiliki siswa melalui pembelajaran matematika yang ditetapkan oleh NCTM (2000) salah satunya, yaitu koneksi (connection) yang termasuk pada keterampilan berpikir matematika tingkat tinggi (high order mathematical thinking) yang harus dikembangkan dalam proses pembelajaran matematika.

Lemahnya kemampuan koneksi matematis siswa Indonesia tidak hanya dapat dilihat dari hasil survei TIMSS dan PISA, tetapi juga dapat dilihat dari penelitian dan survei yang dilakukan oleh para pendidik di Indonesia. Berdasarkan survei yang dilakukan oleh Suryadi, dkk (Yulianti, 2004) di beberapa kota besar, seperti: Bandung, Yogyakarta dan Malang diperoleh keterangan bahwa sebagian besar siswa mengalami kesulitan dalam hal pembuktian teorema, penggunaan penalaran matematis untuk memecahkan masalah, proses menggeneralisasi, penyelesaian soal-soal geometri, pemodelan matematika, serta penemuan hubungan di antara data-data yang diketahui (koneksi matematis).

Salah satu variasi pembelajaran yang dapat dilakukan untuk mengatasi kesulitan dalam membantu proses pembuatan koneksi siswa adalah pendekatan pembelajaran visual thinking. Berpikir visual (visual thinking) dapat menjadi 
sumber alternatif bagi siswa bekerja dalam matematika. Sebagaimana yang diungkapkan oleh Thornton (2001) bahwa visual thinking dalam pembelajaran matematika sekolah dapat menyediakan pendekatan yang sederhana, mudah, luwes dan sangat ampuh untuk mengembangkan penyelesaian matematis dalam proses pembuatan koneksi.

Diharapkan dengan visual thinking dalam pembelajaran matematika dapat menjadi jembatan yang mampu meningkatkan kemampuan pemecahan masalah dan koneksi matematis. Oleh sebab itu, peneliti tertarik untuk melakukan penelitian dengan judul: "Pengaruh Pendekatan Pembelajaran Visual Thinking dalam Meningkatkan Kemampuan Koneksi Matematis Siswa Sekolah Dasar."

Bertolak dari pemikiran tersebut, maka permasalahan pada penelitian ini adalah sebagai berikut: 1) Apakah peningkatan kemampuan koneksi matematis siswa yang mendapatkan pembelajaran dengan pendekatan visual thinking lebih baik daripada siswa yang mendapat pembelajaran konvensional?; 2) Apakah terdapat pengaruh interaksi antara pembelajaran (visual thinking dan konvensional) dan kemampuan matematis siswa (atas, tengah dan rendah) terhadap peningkatan kemampuan koneksi matematis?; dan 3) Apakah terdapat perbedaan kemampuan koneksi matematis siswa yang mendapatkan pembelajaran dengan pendekatan visual thinking ditinjau dari kemampuan matematis siswa (atas, tengah dan bawah)?.

Penelitian ini diharapkan memberikan manfaat bagi siswa, yaitu pembelajaran matematika dengan pendekatan visual thinking diharapkan dapat meningkatkan kemampuan koneksi matematis siswa. Sementara bagi guru, hasil penelitian ini diharapkan dapat memberikan variasi pendekatan pembelajaran matematika agar dapat diaplikasikan dan dikembangkan menjadi lebih baik sehingga dapat meningkatkan kemampuan koneksi matematis siswa SD.

Visual thinking merupakan salah satu cara berpikir selain dua cara berpikir yang lain (berpikir audio/audiotory thinking dan berpikir kinestetik/kinaesthetic thinking). Menurut Sword (2005) Pemikir visual (visual thinker) berpikir lebih efisien ketika materi ditunjukkan menggunakan diagram, bagan alur, ketepatan waktu, film dan demonstrasi. Visual thinker akan cenderung spasial (keruangan) dan memperhatikan ukuran, ruang dan hubungan. Untuk mengingat informasi mereka sering menggambarkannya dalam bentuk diagram. Visual thinker 
biasanya tidak hanya melihat gambaran umum, tetapi melalui sudut pandang yang lebih jelas dan kreatif dibanding pemikir lainnya. Mereka memerlukan waktu yang lebih banyak untuk mengerti suatu informasi, tetapi pemahaman akhirnya lebih luas.

Arcavi (Rivera, 2011) mendefinisikan visual thinking sebagai kemampuan, proses dan hasil kreasi, interpretasi, penggunaan serta gagasan mengenai gambar, image dan diagram di dalam pikiran, di atas kertas atau menggunakan alat-alat teknologi, dengan tujuan menggambarkan dan mengkomunikasikan informasi, gagasan dan mengembangkan ide-ide sebelumnya serta meningkatkan pemahaman.

Langkah-langkah visual thinking menurut Bolton (2011) adalah: (1) Looking, pada tahap ini, siswa megidentifikasi masalah dan hubungan timbal baliknya, merupakan aktivitas melihat dan mengumpulkan; (2) Seeing, mengerti masalah dan kesempatan, dengan aktivitas menyeleksi dan mengelompokkan; (3) Imagining, mengeneralisasikan langkah untuk menemukan solusi, kegiatan pengenalan pola; (4) Showing and Telling, menjelaskan apa yang dilihat dan diperoleh kemudian mengkomunikasikannya.

Langkah-langkah pembelajaran dengan pendekatan visual thinking pada penelitian ini merujuk pada empat langkah visual thinking yang diungkapkan oleh Bolton, dengan menggunakan media visual, baik berupa model tiruan, benda nyata dalam kehidupan sehari-hari, gambar, diagram, tabel atau video.

NCTM dan Wahyudin dalam Fendrik (2016) yang menyatakan bahwa kemampuan koneksi matematis siswa perlu dikembangkan agar siswa dapat menghubungkan materi yang didapatnya di dalam kelas dengan kehidupan nyata yang dialaminya serta pemahaman mereka lebih dalam dan lebih bertahan lama dalam ingatannya serta dapat membantu kebiasaan mental siswa dalam menyelesaikan masalah yang akan ditemuinya dalam kehidupan sehari-hari. Karena ketika siswa menghadapi masalah, ia akan membentuk pola perilaku intelektual tertentu yang dapat mendorong kesuksesan individu dalam menyelesaikan masalah.

Kemampuan siswa dalam koneksi matematis menurut Croxford (1995) meliputi: 1) mengkoneksikan pengetahuan konseptual dan prosedural; 2) menggunakan matematika pada topik lain (other curriculum areas); 3) 
menggunakan matematika dalam aktivitas kehidupan; 4) melihat matematika sebagai satu kesatuan yang terintegrasi; 5)menerapkan kemampuan berpikir matematis dan membuat model untuk menyelesaikan masalah dalam pelajaran lain, seperti musik, seni, psikologi, sains, dan bisnis; 6) menggunakan dan menghargai koneksi di antara topik-topik dalam matematika; dan 7) mengenal berbagai representasi untuk konsep yang sama.

Koneksi matematis merupakan salah satu hal penting dalam berpikir matematis dan dapat membangun pemahaman matematis. Dengan koneksi, siswa dapat membangun pemahaman baru dari pengetahuan sebelumnya (NCTM, 2000). Standar kemampuan koneksi yang terdapat di NCTM (2000) adalah siswa dapat mengenal dan menggunakan koneksi di antara ideide/gagasan matematis, mengerti bagaimana ide-ide matematis saling berhubungan dan membangun satu sama lain untuk menciptakan keseluruhan yang logis, dan mengenal serta mengaplikasikan matematika dalam konteks di luar matematika.

Menurut Sumarmo (2010) dalam belajar matematika siswa dituntut memahami koneksi antara ide-ide matematis dan antar matematika dan bidang studi lainnya karena topik-topik dalam matematika banyak memiliki relevansi dan manfaat dengan bidang lain, baik di sekolah maupun di luar sekolah. Jika siswa sudah mampu melakukan koneksi antara beberapa ide matematis, maka siswa akan memahami setiap materi matematika dengan lebih dalam dan baik. Selain itu melalui koneksi konsep pemikiran dan wawasan siswa akan semakin terbuka dan luas terhadap matematika karena siswa akan memandang matematika sebagai suatu bagian yang terintegrasi bukan sebagai sekumpulan topik yang terpisahpisah, serta mengakui adanya keterkaitan atau hubungan dan aplikasi di dalam kehidupan atau lingkungan sekitar siswa.

\section{METODE PENELITIAN}

Tujuan penelitian ini adalah untuk melihat dan menelaah peningkatan kemampuan koneksi matematis siswa yang memperoleh pembelajaran dengan pendekatan visual thinking. Untuk melihat besarnya peningkatan koneksi matematis siswa, kedua kelas diberikan pretes dan postes. Pretes diberikan sebelum proses pembelajaran dalam penelitian ini dimulai, sedangkan postes 
setelah keseluruhan proses pembelajaran selesai. Pretes diberikan bertujuan untuk melihat kesetaraan kemampuan awal kedua kelompok. Dan postes diberikan bertujuan untuk mengetahui sejauh mana pengaruh pembelajaran yang diberikan terhadap peningkatan kemampuan siswa, melihat apakah terdapat perbedaan kemampuan yang signifikan diantara kedua kelas tersebut.

Penelitian ini bertujuan mengkaji perlakuan berupa pembelajaran dengan pendekatan visual thinking dan pengaruhnya terhadap kemampuan koneksi matematis. Menurut Sugiyono (2010) penelitian seperti ini merupakan penelitian eksperimen. Penelitian eksperimen merupakan metode penelitian yang dilakukan untuk mencari pengaruh treatment (perlakuan) tertentu.

Penelitian melibatkan dua kelas, yaitu kelas eksperimen dan kelas kontrol. Kelas eksperimen adalah kelas yang memperoleh pembelajaran dengan pendekatan visual thinking dan kelas kontrol adalah kelas yang memperoleh pembelajaran konvensional.

Desain penelitian ini adalah quasi eksperimentnonequivalen control group, karena siswa yang menjadi responden pada penelitian ini tidak dipilih secara acak, melainkan peneliti menggunakan kelas yang ada. Diagram desain penelitian seperti ini menurut Ruseffendi (2003) adalah sebagai berikut :

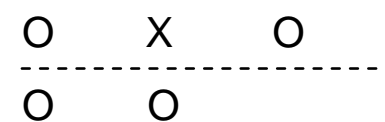

Keterangan :

$\mathrm{O}=$ pretes dan postes

$\mathrm{X}=$ pendekatan pembelajaran visual thinking

Populasi pada penelitian ini adalah siswa Sekolah Dasar di Kota Pekanbaru. Karena tidak mungkin mempelajari semua yang ada pada populasi, maka peneliti menggunakan sampel yang diambil dari populasi. Penentuan sampel dilakukan dengan cara purposive sampling, yaitu teknik pengambilan sampel berdasarkan pertimbangan tertentu (Sugiyono, 2010).

Kelas eksperimen dan kelas kontrol yang merupakan sampel pada penelitian ini dipilih berdasarkan pertimbangan guru matematika di sekolah tersebut dengan mengambil kelas yang sudah ada. Hal ini juga dikarenakan pihak sekolah tidak mengizinkan terjadinya pengacakan terhadap kelas yang sudah ada disebabkan kekhawatiran dapat mengganggu proses pembelajaran. Sampel yang 
dipilih dalam penelitian ini adalah siswa kelas V salah satu Sekolah Dasar di Kota Pekanbaru. Penelitian ini dilaksanakan di salah satu Sekolah Dasar di Kota Pekanbaruyang ada di Kecamatan Bukit Raya, Provinsi Riau. Penelitian ini dilaksanakan di kelas V semester genap tahun pelajaran 2016/2017.

\section{HASIL PENELITIAN}

Pada Tabel 1 dibawah ini disajikan statistik deskriptif mengenai skor pretes, postes dan gain ternormalisasi kemampuan koneksi matematis siswa.

Tabel 1

Statistik Deskriptif Kemampuan Koneksi Matematis

\begin{tabular}{|c|c|c|c|c|c|c|c|c|c|c|c|c|c|c|}
\hline \multirow{3}{*}{$\begin{array}{l}\text { Kelomp } \\
\text { ok }\end{array}$} & \multicolumn{7}{|c|}{ Visual Thinking } & \multicolumn{7}{|c|}{ Konvensional } \\
\hline & \multirow{2}{*}{$\mathbf{N}$} & \multicolumn{2}{|c|}{ Pretes } & \multicolumn{2}{|c|}{ Postes } & \multicolumn{2}{|c|}{$\mathrm{N}$-gain } & \multirow{2}{*}{$\mathbf{N}$} & \multicolumn{2}{|c|}{ Pretes } & \multicolumn{2}{|c|}{ Postes } & \multicolumn{2}{|c|}{$\mathrm{N}$-gain } \\
\hline & & $\bar{x}$ & $\mathbf{s}$ & $\bar{x}$ & $\mathbf{s}$ & $\bar{x}$ & $\mathbf{s}$ & & $\bar{x}$ & $\mathbf{s}$ & $\overline{\bar{x}}$ & $\mathrm{~S}$ & $\bar{x}$ & $\mathbf{s}$ \\
\hline Atas & 8 & 5,75 & 1,69 & 8,12 & 3,36 & 0,29 & 0,43 & 10 & 2,11 & 1,36 & 3,56 & 3,12 & 0,23 & 0,19 \\
\hline Tengah & 15 & 2,47 & 1,96 & 5,60 & 3,02 & 0,32 & 0,34 & 16 & 1,94 & 1,55 & 4,39 & 2,43 & 0,24 & 0,21 \\
\hline Bawah & 8 & 2,25 & 3,20 & 3,88 & 3,04 & 0,17 & 0,31 & 9 & 0,89 & 1,54 & 4,33 & 2,55 & 0,15 & 0,30 \\
\hline Total & 31 & 3,26 & 2,66 & 5,80 & 3,19 & 0,28 & 0,35 & 35 & 1,72 & 1,54 & 4,17 & 2,59 & 0,30 & 0,23 \\
\hline
\end{tabular}

Pada Tabel 1 dapat dilihat bahwa rerata skor pretes, postes dan gain ternormalisasi kemampuan koneksi matematis siswa kelas eksperimen sedikit lebih tinggi dibanding rerata skor kelas kontrol. Bahkan rerata skor peningkatan kemampuan koneksi matematis siswa kelas eksperimen hanya berbeda 0,05 dari peningkatan kemampuan koneksi di kelas kontrol. Begitu pula halnya dengan penyebaran data skor pretes, postes dan gain ternormalisasi. Penyebaran data kemampuan koneksi matematis siswa kelas eksperimen lebih luas daripada kelas kontrol. Peningkatan kemampuan koneksi matematis siswa di kedua kelas termasuk kategori rendah.

Peningkatan kemampuan koneksi matematis pada siswa yang memperoleh pembelajaran dengan pendekatan visual thinking paling besar terjadi pada siswa kelompok tengah, walaupun tidak berbeda jauh dari kelompok atas, perbedaaannya hanya 0,03 lebih besar untuk kelompok tengah. Peningkatan siswa kelompok tengah di kelas eksperimen termasuk kategori sedang, dan dua kelompok lainnya berada pada kategori rendah. Sama halnya dengan kelas eksperimen, di kelas kontrol peningkatan kemampuan koneksi yang paling besar juga terjadi di kelompok tengah, namun termasuk kategori rendah. Bila peningkatan kedua kelompok tengah kedua kelas (eksperimen dan kontrol) 
dibandingkan, maka terlihat bahwa peningkatan kemampuan koneksi matematis siswa yang memperoleh pembelajaran visual thinking pada kelompok tengah lebih besar sekitar 30\% dibanding siswa kelompok tengah siswa yang memperoleh pembelajaran konvensional.

Dari Tabel 1 juga dapat dilihat bahwa pada kelas eksperimen, siswa kelompok tengah mengalami peningkatan kemampuan koneksi matematis yang paling besar dibanding kelompok atas dan bawah. Berbeda dari kelas eksperimen, pada kelas kontrol siswa kelompok bawah justru mengalami peningkatan kemampuan koneksi matematis yang paling tinggi dibanding dua kelompok lainnya. Gain ternormalisasi kemampuan koneksi kelompok tengah di kelas eksperimen dan kelompok bawah di kelas kontrol tergolong sedang, sedangkan gain ternormalisasi yang lainnya tergolong rendah.

Analisis uji kesamaan rerata skor pretes koneksi bertujuan untuk melihat apakah terdapat perbedaan yang signifikan kemampuan awal (kemampuan sebelum pembelajaran) antara kelas eksperimen dan kelas kontrol. Sebelum melakukan uji kesamaan rerata pretes, terlebih dahulu diperiksa apakah skor pretes berdistribusi normal dan bervariansi homogen. Jika pretes berdistribusi normal dan bervarians homogen maka dilanjutkan dengan uji-t, sedangkan jika normal tetapi tidak homogen maka digunakan uji-t' dan untuk skor pretes yang tidak berdistribusi normal maka digunakan uji non-parametrik $U$ Mann-Withney.

Kriteria uji yang digunakan adalah tolak $\mathrm{H}_{0}$ jika $p$-value lebih kecil dari taraf signifikansi $\alpha=0,05$, selain itu diterima. Hasil uji normalitas disajikan dalam Tabel berikut.

Tabel 2

Hasil Uji Normalitas Pretes Kemampuan Koneksi Matematis

\begin{tabular}{|c|c|c|c|c|c|}
\hline Aspek & \multirow{2}{*}{$\begin{array}{c}\text { Sembelajaran } \\
\text { Kemapuan }\end{array}$} & Pemapiro-Wilk & \multirow{2}{*}{ Kesimpulan } \\
\cline { 3 - 6 } Koneksi & Sisual Thinking & 0,912 & 31 & 0,014 & Tolak $\mathrm{H}_{0}$ \\
\cline { 2 - 6 } Matematis & Konvensional & 0,891 & 36 & 0,002 & Tolak $\mathrm{H}_{0}$ \\
\hline
\end{tabular}

Dapat dilihat pada Tabel 2 bahwa nilai signifikansi ( $p$-value) di kedua kelas, kelas dengan pembelajaran visual thinking dan kelas dengan pembelajaran konvensional masing-masing untuk aspek kemampuan koneksi matematis adalah 0,014 dan 0,002 . Nilai ini lebih kecil dibanding taraf signifikansi $\alpha$, artinya $\mathrm{H}_{0}$ 
ditolak. Dengan demikian, rerata skor pretes, baik di kelas eksperimen maupun kelas kontrol untuk kemampuan koneksi matematis tidak berdistribusi normal.

Karena pretes kemampuan koneksi matematis kelas eksperimen dan kelas kontrol tidak berdistribusi normal, maka dilanjutkan dengan uji non-parametrik $U$ Mann-Whitney.

Uji kesamaan rerata pretes dilakukan untuk melihat apakah kemampuan awal koneksi matematis siswa kelas eksperimen berbeda dari kelas kontrol.

\section{Tabel 3}

Hasil Uji U Mann-Whitney Pretes Kemampuan Koneksi Matematis

\begin{tabular}{|l|c|}
\hline & Koneksi Matematis \\
\hline Uji Mann-Whitney & 367,500 \\
\hline Asymp.Sig.(2-tailed) & 0,015 \\
\hline Kesimpulan & Tolak $\mathrm{H}_{0}$ \\
\hline
\end{tabular}

Tabel 3 menunjukkan bahwa nilai signifikansi uji U Mann-Whitney untuk kemampuan awal koneksi matematis adalah 0,015, nilai ini lebih kecil dibanding taraf signifikansi $\alpha=0,05$, sehingga $\mathrm{H}_{0}$ ditolak. Artinya, terdapat perbedaan kemampuan awal koneksi matematis antara kelas eksperimen dan kelas kontrol. Nilai Sig.(1-tailed) $=\frac{1}{2}$ Sig.(2-tailed), sehingga nilai Sig.(1-tailed) $=0,0075$, juga lebih kecil dari 0,05. Jadi dapat disimpulkan bahwa kemampuan awal koneksi matematis siswa eksperimen lebih baik dibanding kelas kontrol.

Seperti diperlihatkan pada Tabel 1 bahwa peningkatan kemampuan koneksi matematis siswa kelas eksperimen menunjukkan peningkatan yang lebih besar dibanding kelas kontrol, walaupun perbedaannya hanya 0,05. Untuk melihat apakah perbedaan ini signifikan, maka perlu dilakukan uji lebih lanjut. Dalam hal ini digunakan uji ANOVA dua jalur, selain untuk melihat apakah peningkatan kemampuan koneksi matematis kelas eksperimen dan kelas kontrol berbeda secara signifikan, uji ANOVA dua jalur juga digunakan untuk melihat apakah terdapat pengaruh interaksi antara pembelajaran dan KKM terhadap peningkatan kemampuan koneksi matematis siswa.

Kriteria yang digunakan adalah jika signifikansi lebih besar dari taraf signifikansi $\alpha=0,05$, maka $\mathrm{H}_{0}$ diterima, dalam hal lainnya $\mathrm{H}_{0}$ ditolak. Hipotesis yang diajukan adalah: "Peningkatan kemampuan koneksi matematis siswa yang memperoleh pembelajaran dengan pendekatan visual thinking lebih baik dibanding siswa yang memperoleh pembelajaran konvensional". 
Selanjutnya hasil uji ANOVA dua jalur dua jalur dapat dilihat pada Tabel 4

Tabel 4

Uji ANOVA Dua Jalur Peningkatan Kemampuan Koneksi Matematis

\begin{tabular}{|c|c|c|c|c|c|c|}
\hline & $\begin{array}{c}\text { Jumalah } \\
\text { Kuadrat }\end{array}$ & df & $\begin{array}{c}\text { Rerata } \\
\text { Kuadrat }\end{array}$ & F & Sig. & Kesimpulan \\
\hline Pembelajaran & 0,016 & 1 & 0,016 & 0,181 & 0,672 & Terima $\mathrm{H}_{0}$ \\
\hline KKM & 0,047 & 2 & 0,023 & 0,266 & 0,767 & Terima $\mathrm{H}_{0}$ \\
\hline Interaksi & 0,172 & 2 & 0,086 & 0,978 & 0,382 & Terima $\mathrm{H}_{0}$ \\
\hline Error & 5,372 & 61 & 0,088 & & \\
\hline Total & 9,869 & 67 & \multicolumn{7}{|l}{} \\
\hline
\end{tabular}

Dari tabel diatas, dapat disimpulkan bahwa tidak terdapat perbedaan peningkatan kemampuan koneksi matematis antara kelas eksperimen dan kelas kontrol. Dan tidak terdapat pengaruh interaksi antara pembelajaran dan KKM terhadap peningkatan kemampuan koneksi matematis.

Berdasarkan hasil uji ANOVA dua jalur diketahui bahwa peningkatan kemampuan koneksi matematis antara siswa yang memperoleh pembelajaran dengan pendekatan visual thinking tidak berbeda secara signifikan dengan peningkatan kemampuan koneksi matematis siswa yang memperoleh pembelajaran konvensional, sehingga tidak perlu lagi dilanjutkan untuk menguji bahwa peningkatan kemampuan koneksi matematis siswa kelas eksperimen lebih baik dibanding siswa di kelas kontrol.

Langkah awal yang harus dilakukan untuk menguji perbedaan kemampuan koneksi matematis siswa yang memperoleh pendekatan pembelajaran visual thinking berdasarkan KKM adalah menguji kenormalan distribusi rerata dan homogenitas varians skor postes kemampuan koneksi matematis kelas eksperimen. Hasil perhitungan uji normalitas skor postes kemampuan koneksi matematis kelas eksperimen berdasarkan kelompok kemampuan matematis siswa disajikan dalam Tabel 5 :

Tabel 5.

Uji Normalitas Kemampuan Koneksi Matematis Kelas Eksperimen

\begin{tabular}{|c|c|c|c|}
\hline \multirow{2}{*}{ Kategori } & \multicolumn{3}{|c|}{ Kolmogorov-Smirnov } \\
\cline { 2 - 4 } & Statistik & df & Sig. \\
\hline Atas & 0,162 & 8 & 0,200 \\
\hline Tengah & 0,247 & 15 & 0,014 \\
\hline Bawah & 0,359 & 8 & 0,003 \\
\hline & & & \\
\hline
\end{tabular}


Berdasarkan Tabel 5 diatas terlihat bahwa nilai signifikansi dua kategori, yaitu kategori rendah dan tinggi lebih kecil dibanding nilai $\alpha=0,05$ maka disimpulkan bahwa data kemampuan koneksi matematis kelas eksperimen tidak berdistribusi normal, sehingga uji yang dilakukan adalah uji Kruskal-Wallis. Adapun hipotesis yang diuji adalah: "Tidak terdapat perbedaan kemampuan koneksi matematis siswa yang memperoleh pembelajaran dengan pendekatan visual thinking ditinjau dari kemampuan matematis siswa (atas, tengah dan bawah)".

Hasil perhitungan uji Kruskal-Wallis mengenai kemampuan koneksi matematis siswa yang memperoleh pendekatan pembelajaran visual thinking disajikan pada Tabel 6 :

Tabel 6

Uji Signifikansi Perbedaan Kemampuan Koneksi Matematis Kelas Eksperimen berdasarkan KKM

\begin{tabular}{|c|c|}
\hline & Koneksi Matematis \\
\hline Chi-square & 8,413 \\
\hline Df & 2 \\
\hline Asymp.Sig. & 0,015 \\
\hline
\end{tabular}

Dari tabel diatas terlihat bahwa signifikansi uji adalah 0,015, nilai ini lebih kecil dari nilai signifikansi $\alpha(0,05)$, sehingga $\mathrm{H}_{0}$ ditolak. Artinya terdapat minimal dua yang berbeda untuk kemampuan koneksi matematis siswa antar kelompok kemampuan atas, tengah dan bawah pada kelas yang memperoleh pembelajaran dengan pendekatan visual thinking.

Data hasil perhitungan uji Kruskal-Wallis dapat dilihat pada Tabel 7 :

Tabel 7

Uji Kruskal-Wallis Lanjutan Kemampuan Koneksi Matematis berdasarkan KKM Siswa di Kelas Eksperimen

\begin{tabular}{|c|c|c|c|c|c|c|}
\hline$\underset{U}{\text { Kelompok }}$ & $\underset{v}{\text { Kelompok }}$ & $\overline{R_{u}}$ & $\overline{\boldsymbol{R}_{v}}$ & $\left|\overline{R_{u}}-\overline{R_{v}}\right|$ & $\mathbf{Z}^{*}$ & Kesimpulan \\
\hline \multirow{2}{*}{ Atas } & Tengah & \multirow{2}{*}{4,5} & 15,5 & 11 & 9,94 & Tolak Ho \\
\hline & Bawah & & 27 & 22,5 & 10,58 & Tolak Ho \\
\hline \multirow{2}{*}{ Tengah } & Atas & \multirow{2}{*}{15,5} & 4,5 & 11 & 9,94 & Tolak Ho \\
\hline & Bawah & & 27 & 11,5 & 9,60 & Tolak Ho \\
\hline \multirow{2}{*}{ Bawah } & Atas & \multirow{2}{*}{27} & 4,5 & 22,5 & 10,58 & Tolak Ho \\
\hline & Tengah & & 15,5 & 11,5 & 9,60 & Tolak Ho \\
\hline
\end{tabular}


Tabel 7 menunjukkan bahwa terdapat perbedaan yang signifikan kemampuan koneksi matematis pada setiap kelompok kemampuan matematis siswa yang memperoleh pembelajaran dengan pendekatan visual thinking.

Seluruh hasil pengujian hipotesis pada penelitian ini dirangkum dalam Tabel 8 berikut:

\section{Tabel 8}

Rangkuman Pengujian Hipotesis Penelitian

\begin{tabular}{|c|l|c|c|}
\hline No & \multicolumn{1}{|c|}{ Hipotesis Penelitian } & $\begin{array}{c}\text { Jenis Uji } \\
\text { Statistik }\end{array}$ & $\begin{array}{c}\text { Hasil } \\
\text { Uji }\end{array}$ \\
\hline 1 & $\begin{array}{l}\text { Peningkatan kemampuan koneksi matematis siswa } \\
\text { yang mendapatkan pembelajaran dengan pendekatan } \\
\text { visual thinking lebih baik daripada siswa yang } \\
\text { mendapat pembelajaran konvensional. }\end{array}$ & $\begin{array}{c}\text { ANOVA } \\
\text { 2 Jalur }\end{array}$ & $\begin{array}{c}\text { Terima } \\
\mathrm{H}_{0}\end{array}$ \\
\hline 2 & $\begin{array}{l}\text { Tidak terdapat pengaruh interaksi antara } \\
\text { pembelajaran (visual thinking dan konvensional) dan } \\
\text { kemampuan matematis siswa (atas, tengah dan } \\
\text { bawah) terhadap peningkatan kemampuan koneksi } \\
\text { matematis. }\end{array}$ & $\begin{array}{c}\text { ANOVA } \\
\text { 2 Jalur }\end{array}$ & $\begin{array}{c}\text { Terima } \\
\mathrm{H}_{0}\end{array}$ \\
\hline 3 & $\begin{array}{l}\text { Tidak terdapat perbedaan kemampuan koneksi } \\
\text { matematis siswa yang mendapatkan pembelajaran } \\
\text { dengan pendekatan visual thinking ditinjau dari } \\
\text { kemampuan matematis siswa (atas, tengah dan } \\
\text { bawah). }\end{array}$ & $\begin{array}{c}\text { Kruskal- } \\
\text { Wallis }\end{array}$ & $\begin{array}{c}\text { Tolak } \\
\mathrm{H}_{0}\end{array}$ \\
\hline
\end{tabular}

Dari hasil analisis data skor pretes menunjukkan bahwa kemampuan awal kelas eksperimen yang memperoleh pembelajaran dengan pendekatan visual thinking dan kelas kontrol yang memperoleh pembelajaran kelas kontrol tidak berbeda secara signifikan pada kemampuan koneksi matematis, kemampuan awal koneksi matematis siswa yang memperoleh pembelajaran dengan pendekatan visual thinking lebih baik dibanding siswa yang memperoleh pembelajaran konvensional. Artinya kemampuan koneksi matematis siswa kelas eksperimen dan kelas kontrol pada kemampuan awal tidak sama.

Penurunan terjadi pada kemampuan koneksi matematis. Penurunan ini terjadi disebabkan beberapa hal, yaitu kecerobohan dan ketidaktelitian dalam proses perhitungan, kesalahan dalam memasukkan rumus dan terlalu fokus pada penyelesaian nomor soal lainnya sehingga kekurangan waktu untuk mengerjakan soal-soal koneksi matematis. Hal ini merupakan dampak dari siswa-siswa yang sadar bahwa soal pretes sama dengan soal postes, sehingga tidak hati-hati dalam mengerjakan soal-soal ketika postes. 
Peningkatan kemampuan koneksi matematis siswa yang memperoleh pembelajaran dengan visual thinking tidak berbeda secara signifikan dengan siswa yang memperoleh pembelajaran konvensional, tetapi terdapat perbedaan kemampuan koneksi matematis yang signifikan di ketiga kelompok kemampuan matematis siswa (atas, tengah dan bawah). Interaksi antara pembelajaran dengan kemampuan matematis tidak memberikan pengaruh terhadap peningkatan kemampuan koneksi matematis.

Tidak terdapat pengaruh interaksi antara pembelajaran dengan kemampuan matematis siswa terhadap peningkatan kemampuan koneksi matematis menunjukkan bahwa pembelajaran (visual thinking dan konvensional) lebih berperan pada peningkatan kemampuan koneksi matematis dibandingkan dengan kemampuan matematis siswa (atas, tengah dan bawah). Hal ini mengimplikasikan bahwa peran guru dalam pembelajaran lebih berarti dibanding kemampuan matematis siswa.

Penyebab rendahnya hasil pembelajaran dengan pendekatan visual thinking pada kemampuan koneksi matematis adalah tidak munculnya koneksi internal (koneksi anatar konsep matematika) dalam aktivitas pembelajaran dengan pendekatan visual thinking. Hal ini diperparah dengan kurangnya penguasaan siswa terhadap materi prasyarat, khususnya mengenai sudut dan perubahan satuan. Sebagaimana disebutkan oleh Wahyudin (1999) bahwa kecenderungan siswa gagal menguasai dengan baik pokok bahasan geometri ruang di antaranya siswa kurang menguasai dengan baik konsep-konsep dasar matematika serta siswa kurang memiliki penguasaan materi prasyarat dengan baik. Hal ini sejalan dengan apa yang dikemukakan oleh Sagala (2005) bahwa keberhasilan belajar siswa diperlukan prasyarat tertentu diantaranya menguasai bahan-bahan dasar yang diperlukan untuk meneruskan pelajaran sekolah yang menjadi lanjutannya.

Kurangnya penguasaan konsep sudut terlihat saat proses belajar mengajar, yaitu ketika menggambar bangun dan melukis jaring-jaring bangun ruang sisi datar (pada pertemuan pertama), terutama bangun prisma dan limas. Siswa masih kesulitan menentukan sudut yang tepat agar diperoleh gambar dan jaring-jaring yang benar.

Berdasarkan hasil yang diperoleh dapat dikatakan bahwa pembelajaran dengan pendekatan visual thinking untuk meningkatkan kemampuan koneksi 
matematis, peningkatan yang terjadi, yaitu 5,80 dari skor ideal maksimal 12 . Artinya, pembelajaran yang dilakukan belum bisa dikatakan berhasil.

Kemungkinan penyebab ketidakberhasilan pembelajaran dengan pendekatan visual thinking adalah kurangnya soal-soal latihan yang diberikan karena terlalu fokus dalam kegiatan pembelajaran dan kurang bervariasinya soalsoal yang diberikan. Pembelajaran dengan pendekatan visual thinking menyebabkan meningkatnya kecerobohan siswa dalam mengerjakan soal. Hal ini didukung oleh pernyataan Zahar (2009) bahwa berpikir visual dapat menyebabkan siswa kurang teliti, walaupun siswa tersebut pintar dalam matematika. Dalam mengerjakan soal-soal tes, siswa kurang mampu membaca soal yang diantaranya disebabkan oleh kurang teliti membaca soal, salah penafsiran terutama soal yang tidak mengandung angka (soal nomor 3) dan ceroboh dalam perhitungan teknis. Hal ini didukung oleh pernyataan Wardhani dan Rumiati (2011) bahwa siswa Indonesia kurang mampu membaca soal yang disebabkan oleh kurang teliti membaca soal, salah penafsiran atau mengalihkan soal ke proses mekanis.

\section{SIMPULAN DAN SARAN}

Berdasarkan hasil pengolahan data, analisis, temuan dan pembahasan yang telah disajikan sebelumnya, diperoleh kesimpulan, yaitu: 1) Peningkatan kemampuan koneksi matematis siswa yang memperoleh pembelajaran dengan pendekatan visual thinking tidak berbeda secara signifikan dibanding siswa yang memperoleh pembelajaran konvensional; 2) Tidak terdapat interaksi antara pembelajaran (visual thinking dan konvensional) dengan kemampuan matematis siswa (atas, tengah dan bawah) terhadap peningkatan kemampuan koneksi matematis.; dan 3) Terdapat perbedaan kemampuan koneksi matematis siswa yang memperoleh pembelajaran dengan pendekatan visual thinking ditinjau dari kemampuan matematis siswa (atas, tengah dan bawah). Kemampuan koneksi matematis siswa yang memperoleh pembelajaran visual thinking berbeda di ketiga kelompok kemampuan matematis. Dan diharapkan guru dapat menggunakan pendekatan ini kepada siswa secara kreatif dan efektif. 


\section{DAFTAR PUSTAKA}

Bolton, S. (2011). Decoding Visual Thinking. Naver Workshop, Visualising Creative Strategies. [Online]. Tersedia http://issuu.com/gpbr/docs/decodingvisualthinking. [2 Januari 2012].

Coxford, A.F. (1995). "The Case for Connections" dalam Connecting Mathematics Across The Curriculum. NCTM Yearbook.

Fendrik. (2016). Analisis Kemampuan Koneksi Matematis Siswa Kelas V Sekolah Dasar. Jurnal Pendidikan Serantau, 2 (2), (173-186).

National Council of Teachers of Mathematics. (2000). Principles and Standard forSchool Mathematics. Reston : NCTM.

Rivera, F .(2011). Toward a Visually-Oriented School Mathematics Curriculum, Research, Theory, Practice, and Issues. California : San Jose State University.

Ruseffendi, E.T. (2003). Dasar-dasar Penelitian Pendidikan dan Bidang Non Ekasakta Lainnya. Bandung : Tarsito.

Sagala, S. (2005). Konsep dan Makna Pembelajaran. Bandung : Alfabeta.

Sugiyono. (2010). Metode Penelitian Pendidikan. Bandung : Alfabeta.

Sumarmo, U. (2010). Berpikir dan Disposisi Matematik: Apa, Mengapa dan Bagaimana Dikembangkan pada Peserta Didik. Bandung : Universitas Pendidikan Indonesia. Tidak Diterbitkan.

Sword, L.K. (2005). The Power of Visual Thinking. Gifted and Creative Service Australia. [Online]. Tersedia: www.giftedservice.com.au. [7 Oktober 2011].

Thornton, S. (2001). A Picture is Worth A Thousand Words. [Online]. Tersedia: http://math.unipa.it/ grim/AThornton251.PDF [7 Oktober 2011].

Wahyudin. (1999). Kemampuan Guru Matematika, Calon Guru Matematika dan Siswa dalam Mata Pelajaran Matematika. Disertasi Universitas Pendidikan Indonesia. Tidak diterbitkan.

Wardhani, S dan Rumiati. (2011). Instrumen Penilaian Hasil Belajar Matematika SMP: Belajar dari PISA dan TIMSS. Yogyakarta : Pusat Pengembangan dan Pemberdayaan Pendidik dan Tenaga Kependidikan Matematika.

Yulianti, K. (2004). Penerapan Model Siklus Belajar (Learning Cycle) pada Pembelajaran Barisan dan Deret dalam Upaya Meningkatkan Koneksi Matematik Siswa. Skripsi Universitas Pendidikan Indonesia. Tidak Diterbitkan.

Zahar, I. (2009). Belajar Matematikaku: Pembelajaran Matematika secara Visual dan Kinestetik. Jakarta : Elex Media Komputindo. 